\title{
Necrotic thymoma with cardiac compression in a young lady
}

\author{
E Likaj, , A Kacani, S Dumani, D Hasi, A Alia, A Kenga, L Dibra, A Refatllari \\ From 23rd World Congress of the World Society of Cardio-Thoracic Surgeons \\ Split, Croatia. 12-15 September 2013
}

\section{Background}

Necrosis, infarction and cystic degeneration in thymoma are described mostly focally. Extensive cystic and necrotic degenerations are reported very rarely.

\section{Methods}

A 30-year-old female patient presented with a history of three months complaining of interscapular chest pain and progressive dyspnea on exertion. Last two weeks she had nocturnal dyspnea and excessive chest pain. The patient had no clinical signs of myasthenia gravis. Radiological investigations revealed a mass lesion of $82 \times 55 \times 90 \mathrm{~mm}$ located in the anterior mediastinum without any calcifications or mediastinal extension. Echocardiography showed compression of the right ventricle with dilatation of the inferior vena cava.

\section{Results}

The patient was operated on standard median sternotomy. During the operation, a well encapsulated large tumor tissue was observed. Macroscopically it was suggestive of thymoma with large areas of necrosis and caseous tissues. No infiltration of the pleura or pericardium was observed. The tumor was completely removed. The postoperative course was free of complications, except an inflammatory syndrome with subfebrile temperature ranging 37,5 to 38,0 for a period of 5 days. Histopathological examination confirmed the diagnosis of a type A thymoma with large areas of necrotic tissues and cystic degeneration. At control after four years no signs of recurrence of the disease are noted on computed tomography.
* Correspondence: ermallikaj@yahoo.com

Cardiovascular Surgery Department, University Hospital Centre "Mother Theresa", Tirana, Albania

\section{Conclusions}

Cardiac compression in thymoma is very rare pathology. Early diagnosis and surgical treatment is mandatory. Completeness of resection is a reliable prognostic factor.

Published: 11 September 2013

\section{doi:10.1186/1749-8090-8-S1-P29}

Cite this article as: Likaj et al.: Necrotic thymoma with cardiac compression in a young lady. Journal of Cardiothoracic Surgery 20138 (Suppl 1):P29.
Submit your next manuscript to BioMed Central and take full advantage of:

- Convenient online submission

- Thorough peer review

- No space constraints or color figure charges

- Immediate publication on acceptance

- Inclusion in PubMed, CAS, Scopus and Google Scholar

- Research which is freely available for redistribution
C Biomed Central 